\title{
Impacts of On-Street Parking Fees in Suburbs
}

\author{
Albania Nissan ${ }^{1}$, Ioannis Ntriankos ${ }^{2}$, Jonas Eliasson $^{3}$, Per Näsman $^{4}$, , Maria Börjesson ${ }^{5}$ \\ ${ }^{1}$ Division for Transport Planning, KTH Royal Institute of Technology, Stockholm, Sweden \\ ${ }^{2}$ The Swedish Transport Administration, Stockholm, Sweden \\ ${ }^{3}$ Department of Science and Technology, Linköping University, Linköping, Sweden \\ ${ }^{4}$ Center for Safety Research, KTH Royal Institute of Technology, Stockholm, Sweden \\ ${ }^{5}$ Swedish National Road and Transport Research Institute, KTH Royal Institute of Technology, Stockholm, Sweden
}

\section{Email address:}

per.nasman@abe.kth.se (P. Näsman)

${ }^{*}$ Corresponding author

\section{To cite this article:}

Albania Nissan, Ioannis Ntriankos, Jonas Eliasson, Per Näsman, MariaBörjesson. Impacts of On-street Parking Fees in Suburbs. International Journal of Transportation Engineering and Technology. Vol. 6, No. 3, 2020, pp. 75-85. doi: 10.11648/j.ijtet.20200603.12

Received: July 14, 2020; Accepted: August 18, 2020; Published: September 10, 2020

\begin{abstract}
Street parking fees are common in many cities across the world. Knowledge on how such fees impact parking demand is crucial for designing charging schemes. Empirical studies of parking fees are however scares and often hampered by a lack of data systematically collected before and after policy changes. Moreover, almost all studies analyzing the impact of fees on parking demand focuses on dense city centers. This paper aims as showing how on-street parking count conducted before and after the introduction of parking fees of in the suburbs of Stockholm impact parking demand. This paper analyses data conducted before and after the implementation of the new parking policy in 2017, where on-street parking fees were introduced for the first time in the inner suburbs. At the same time, the amount of the fee was also increased in the inner city. Moreover, the fine was raised for the parking ticket issued to cars parked in breach of parking regulations. We find a 35-40 percent reduction in the number of parked cars in response to the introduction of parking fees in the suburbs. However, the increase in the parking fees in the inner city had a substantially lower effect or no effect at all on demand. The effect of increasing the amount of the fine had no impact on the number of the cars violating parking restrictions.
\end{abstract}

Keywords: Parking, On-street Parking, Parking Fees, Demand, Occupancy Rate, Parking Ticket, Suburbs

\section{Introduction}

On-street parking fees and enforcement are imperative in the control of congestion and allocation of scarce street space [1]. Recent development of smart technology also facilitates the payment and monitoring of parking fees. There is some literature on the price elasticity of parking fees, observed after changes in the parking fee rates in city centers [2-5]. However, empirical studies of parking fees are often hampered by a lack of data systematically collected before and after policy changes. Moreover, almost all literature on the effect of parking fees deals with dense city centres. This paper, on the other hand, analyses an on-street parking count conducted before and after the introduction of parking fees of $€ 1 /$ hour ${ }^{1}$ in the inner suburbs of Stockholm, on workdays

1 The conversion rate $10 \mathrm{SEK} / €$ is used throughout this paper. 7am - 7pm. The data is conducted by floating car measurements. We control for possible seasonal effects and explore how the parking fees impact the demand for parking on different weekdays and times-of-day. For comparison, we analyze aggregate effects on parking occupancy of increased/introduced parking fees in the inner city and the inner suburbs using data collected by the City of Stockholm.

Parking fees have been levied in central Stockholm for decades but in 2016 the city decided to introduce fees for street parking outside the inner city, in the inner suburbs. These parking fees were introduced between the autumn of 2016 and the early spring of 2018. The purpose of the parking fees is to accomplish a better match between demand and supply of kerbside parking, reduce cruising time, and to prioritize visitor parking (short-term parking) over long-term parking ("car storage"). The target occupancy level is 85 percent in all zones. The parking fee can be paid using smart cashless mobile apps, which allows the driver to adjust an ongoing parking session 
and remind the driver before it expires.

Empirical estimates of the demand elasticity for parking varies. Using traffic count data, Concas and Nayak [6] use a meta-analysis regression to find an average parking fare demand elasticity of -0.39 (US -0.3) and much higher for nonUS studies (-0.86). Others [7,8] find that on and off-street parking demand is inversely related to the amount of the parking fee. Kobus et al. (2013) find that garage demand elasticities vary from -2.2 (60 min stay) to -1.5 (20 min stay). Based on a before and after survey, Kelly and Clinch's [9] find that an increase in parking prices by 50 percent for kerbside parking in Dublin results in a decrease in parking demand by 15 percent.

The parking elasticities differ between types of areas and location, e.g. residential areas, shopping areas and office areas. Parking charges in shopping areas and office areas impact the modal choice [4, 10-16]. Simicevic et al. (2013), Albert and Mahalel [17] and Tsamboulas [18] all used stated preferences to elicit how parking fees at the destination impact modal choice. As expected, these studies find that the price sensitivity and the impact on modal choice depend on user and trip characteristics such as purpose and the competitiveness of the alternative modes. The scheduling flexibility is also a key factor for mode and parking preferences at the workplace [19]. Underpriced street parking in residential suburbs might impact car ownership. In all types of areas unpriced parking distorts the land market [20], implying that the supply of parking on private land becomes lower than optimal. This in turn reduces space for public transport, slow modes or other activities. In this way, parking policy has a considerable influence on the land use and city mobility [21]. Brooke et al. [22] found that on-street parking search was more likely to occur within peripheral urban areas away from the core city centre, as such areas may be lacking in parking facilities of the type that are typically provided in central urban areas. The area under study is a residential area with multi-family buildings in an inner suburb of Stockholm, close to some larger business and office districts. It is also close to the metro, so some commuters might use the area for park-and-ride. Parking fees in areas such as this can discourage the residents from owning a car, encourage them to rent a parking space, or encourage them to park their car in residential areas further out from the city where fees do not apply. It is also likely that car owners residing in the inner city use kerbside parking in the suburbs. In that case, these car owners are likely to be impacted in a similar way to that of the residents of the suburb.

Since the parking fees only apply daytime weekdays, they can also impact commuting in different ways. They can discourage park-and-ride commuters from accessing the metro in the area, discourage car commuting among workers in the area where parking fees are introduced, or encourage car commuting for those residents in the area that enjoy free parking at work. In the case of the parking fees impacting commuting, we would find a larger effect in day time than in the evenings.

We find that the introduction of parking fees of $€ 1 /$ hour reduced the number of parked cars by as much as 35-40 percent. Interestingly, although parking fees were only introduced during daytime $(7 \mathrm{am}-7 \mathrm{pm})$, the number of parked cars also decreased during the evening, suggesting that modal choice for commuting is not the only effect of the charges. For comparison, an increase in charges from $€ 4$ to $€ 5$ /hour in the CBD of Stockholm did not reduce the number of parked cars. Now, as in most inner cities, on-street parking is underpriced in central Stockholm (i.e. it is lower than the market price set in the private parking garages [1]). Where parking is unpriced one would expect it to be over-exploited in equilibrium, such that demand exceeds the supply [23], also inducing more cruising for parking $[1,24]$. Now, since parking is underpriced before, and to some extent also after the increase in the city centre parking fees, this explains the small effect in central Stockholm. However, in the suburbs there was not much excess demand for parking space before the charges were introduced, resulting in a larger effect. We also find that the effect of increasing the amount of the fine had no impact on the number of the cars violating parking restrictions. There is, however, a steady trend increase in the share of vehicles complying with the parking regulations from 2007 to 2015. A potential reason could be the mobile apps, helping the driver to adjust an ongoing parking session and remind the driver before it expires.

The paper is outlined as follows. In section 2 we describe the parking policy of Stockholm and how it has changed over time. In section 3 we describe and analyze aggregate effects on parking occupancy of increased/introduced parking fees in the inner city and the inner suburbs using data collected by the city of Stockholm. In section 4 we describe the collection of the floating car data, and Section 5 reports the results. Section 6 concludes with a forward-looking summary and policy implications.

\section{Parking Policy Changes}

\subsection{Car Ownership and Car Use}

So how do the residents of the inner suburbs (the purple area of Figure 1) of Stockholm park? According to a large cross-sectional travel survey conducted among 16-84 yearold residents in September-October 2015, 70\% of the residents of the inner suburbs have a car in the household. Of those, just over one fourth use kerbside parking, and just over one fourth park their car in the driveway by their own house. The majority park their car in a parking garage or rent a parking space (Table 1). 39 percent of all their trips are made by car, but only 28 percent of their trips for work or study are made by car (Table 2).

Table 1. Type of parking for households having access to a car, which is 68 percent of the households. Residents in the inner suburbs within the municipality of Stockholm (source 2015 Stockholm travel survey).

\begin{tabular}{ll}
\hline Type of parking & \% \\
\hline in the driveway by their own house & 29 \\
Kerbside parking & 26 \\
Parking garage, reserved parking & 45 \\
Total & 100 \\
\hline
\end{tabular}


One of the main reasons for the low share of car trips is that since the 1950s, Stockholm has followed a transit-oriented satellite town planning strategy $[25,26]$, implying that the land use is concentrated along transit corridors. Moreover, in 2006, Stockholm introduced congestion charges, designed as a toll cordon around the inner city in 2006 [27]. The toll cordon was extended and the peak charge was increased in 2016 [28].

\subsection{The New Parking Policy}

Parking fees were introduced in a few streets in central Stockholm in the 1950s. Over the years, the areas where street parking is charged were extended, to finally cover the entire inner city. Figure 1 shows the zones with different levels of on-street parking fees, with zones 1 and 2 constituting the CBD and zone 3 the rest of the inner city. Figure 2 shows how fee levels have developed in the CBD and in the rest of the inner city since 1985, for visitors (hourly fee) and for residents (monthly resident parking permits). Since the turn of the century, the fee in the inner city has roughly tripled in real terms.

Table 2. Mode shares for residents in the regional centre within the municipality of Stockholm, weekdays (source 2015 Stockholm travel survey).

\begin{tabular}{lll}
\hline Mode share & All trips \% & Work/study trips \% \\
\hline Car & 39 & 28 \\
Transit & 38 & 53 \\
Slow modes & 23 & 19 \\
All modes & 100 & 100 \\
\hline
\end{tabular}

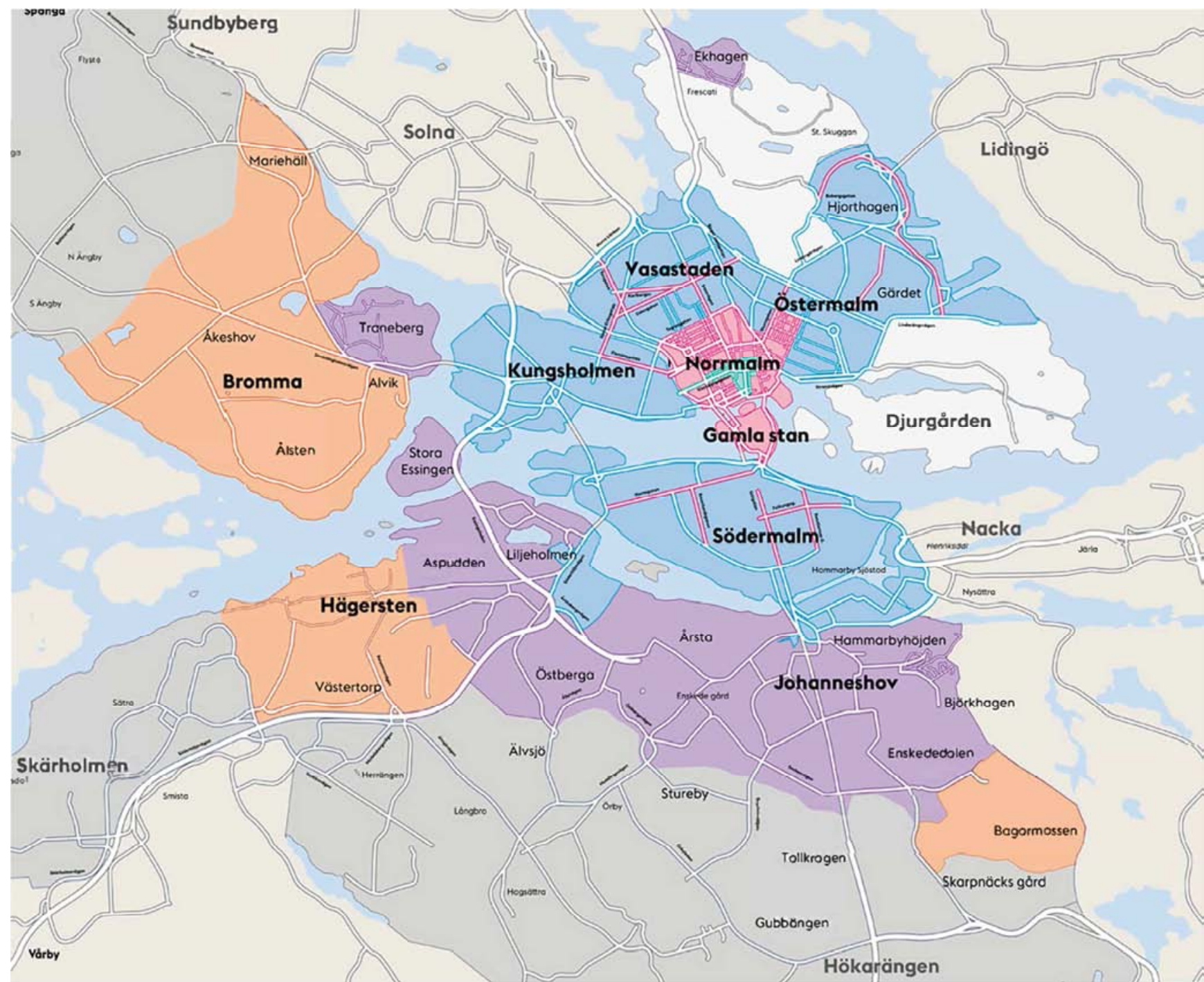

\begin{tabular}{|c|c|c|c|c|}
\hline Tariff I & Tariff 2 & Tariff 3 & Tariff 4 & Tariff 5 \\
\hline$€ 5 / \mathrm{h}$ all days, & $€ 2.6 / \mathrm{h}$ & €1.5/h 7-19 & El/h 7-19 & es/h7-19 \\
\hline $\begin{array}{l}00-24 \\
\text { City Centre }\end{array}$ & $\begin{array}{l}\text { 7-21 (9-19) 9-19 } \\
\text { fl. 5h Other time }\end{array}$ & $€ 1 / h(11-17)$ & $(11-17)$ & \\
\hline
\end{tabular}

Figure 1. Current fees for street-parking. Source city of Stockholm: http://www.stockholm.se/PageFiles/1109380/stor_Taxeområden.jpg. 


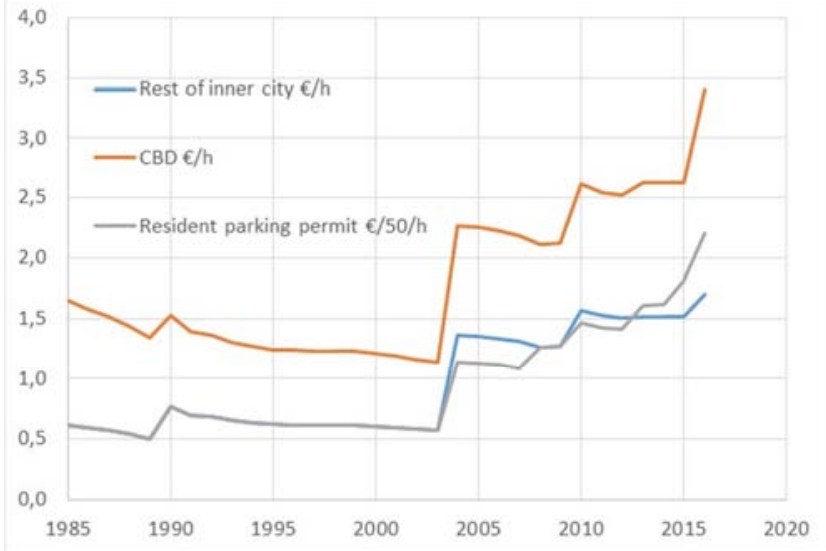

Figure 2. Parking fees in the inner city of Stockholm, at the price level of 2016.

In 2016 the city decided to introduce fees for street parking outside the inner city: in the inner suburbs (zone 4) and the outer city (zone 5); see Table 3 . These parking fees were introduced in the period from the autumn of 2016 to the early spring of 2018. The purpose of the parking fees is to obtain a better match between demand and supply of kerb parking and to prioritize visitor parking (short-term parking) over longterm parking ("car storage"). The target occupancy level is 85 percent in all zones. This reduces traffic cruising for parking.

This paper focuses on the effect of introducing parking fees in zone 4 , where the fee is $€ 1 / \mathrm{h}$ for visitors (weekdays, $7 \mathrm{am}-7 \mathrm{pm}$ ), and the monthly resident parking permit costs $€ 50$ /month. In zone $4,62 \%$ of the blocks comprise multifamily buildings, $21 \%$ comprise single-family houses, and $17 \%$ are not residential areas (e.g. include sports grounds, shops, churches or industries). The share of cars with resident parking permits is 65 percent after the introduction of the parking fees. Specifically, we explore one area within zone 4 in more detail, by collecting floating car data in the area of Midsommarkransen (Figure 3). This area covers an area of $1 \mathrm{~km}^{2}$ and has 11000 inhabitants. These areas are mostly residential areas with multi-family buildings and a limited supply of daily shopping, entertainment and services. There are three metro stations in or close to the area, and several bus routes are accessible from the area. The details of the floating car data collection are given in Section 4. But for comparison, Section 3 first analyzes some more aggregate before-and-after data collected by the city of Stockholm, covering the inner city (zones 1-3) and the inner suburbs (zone 4).

Table 3. Parking fee before and after the change under study (introduced September 2016-January 2018). Hours when the fee applies in weekdays are stated in normal font, Saturdays are in brackets, and Sundays in red italics.

\begin{tabular}{|c|c|c|}
\hline Zone & Before increase & After increase \\
\hline Zone 1 (core CBD) & $€ 4.1 / \mathrm{h}$ at all times. No resident parking permit & $€ 5$ /day at all times. No resident parking permit \\
\hline Zone 2 (CBD) & $\begin{array}{l}€ 2.6 / \mathrm{h} 9-17(9-16), € 1.5 / \mathrm{h} \text { other times. Resident } \\
\text { parking permit: } € 90 / \text { month }\end{array}$ & $\begin{array}{l}€ 26 / \mathrm{h} 7-21(9-19) 9-19, € 1.5 / \mathrm{h} \text { other times. Resident parking permit: } \\
€ 110 / \text { month }\end{array}$ \\
\hline Zone 3 (rest of inner city) & $€ 1.5 / \mathrm{h} 9-17$. Resident parking permit: $€ 90 /$ month & $€ 1.5 / \mathrm{h} 7-19, € 1 / \mathrm{h}(11-17)$. Resident parking permit: $€ 110 /$ month \\
\hline Taxa 4 (inner suburbs) & No parking fee & $€ 1 / \mathrm{h} 7-19$ (11-17). Resident parking permit: $€ 50 /$ month \\
\hline Taxa 5 (suburbs) & No parking fee & $€ 5$ /h 7-19. Resident parking permit: $€ 30 /$ month \\
\hline
\end{tabular}

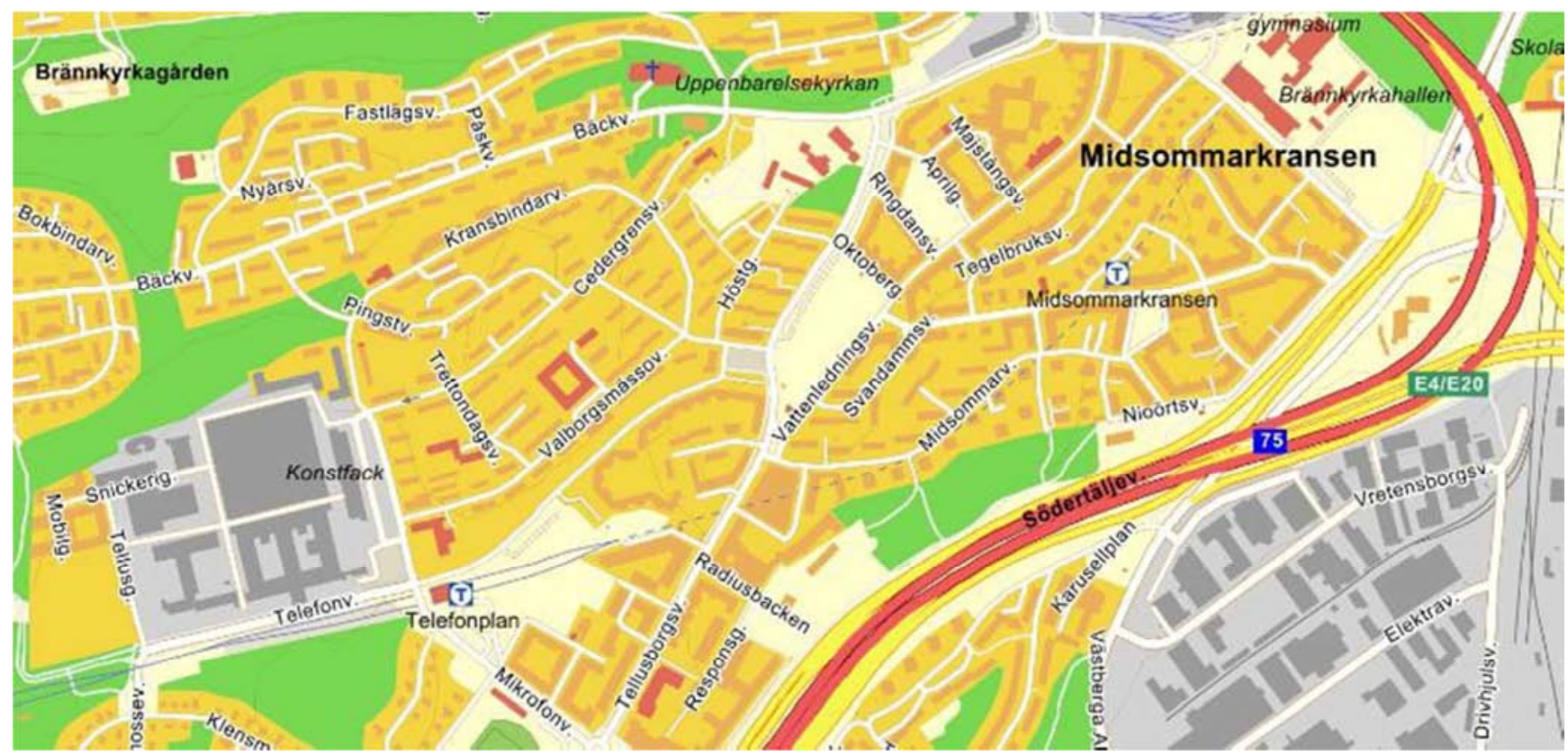

Figure 3. The study area within Midsommarkransen, with the two nearest Metro stations depicted by T. 


\section{Overview of Effects}

\subsection{Inner City}

For many years, the city of Stockholm has monitored occupancy rates and the number of illegally parked cars by manual counts in the inner city (zones 1-3). The number of parked vehicles is counted on 483 randomly selected blocks twice a year, during daytime on weekdays (7am - 7pm). Although the parking charges have increased substantially, the occupancy rate has remained roughly constant at approximately 90 percent (the variation is within one percentage point) since 2008.

The fees in the CBD zone 2 were increased in the period of July 2017- January 2018. The fee increased from $€ 4.1$ /hour to $€ 5$ /hour for visitors and the price of the resident parking permit increased from $€ 90 /$ month to $€ 110$ /month. Therefore, the data conducted in September / October 2016 and Sept / Oct 2018 are compared here. The number of parked cars is counted once for every selected block, such that each street generates one observation per data collection period. The number of cars is converted to occupancy rate by division by maximum capacity. Table 4 shows the average occupancy rates for all streets by data collection period.

Table 4. Occupation rate in the inner city (zones 1-3) before and after increases in the parking fee in the CBD (zone one-two).

\begin{tabular}{lll}
\hline Inner city, daytime & Sept-Oct 2016 & Sept-Oct 2018 \\
\hline Occupancy rate (excl. vehicles breaking traffic rules) & $89 \%$ & $89 \%$ \\
Occupancy rate (incl. vehicles breaking traffic rules) & $94 \%$ & $92 \%$ \\
Number of counted parked vehicles & 11093 & 11177 \\
Share of streets above the target (> 85\%) & $80 \%$ \\
Share of streets below 50\% & $4 \%$ & $76 \%$ \\
Occupancy rate CBD (excl. vehicles breaking traffic rules) & $88 \%$ & $4 \%$ \\
Occupancy rate CBD (incl. vehicles breaking traffic rules) & $98 \%$ & $93 \%$ \\
Share of parked vehicles with resident parking permit & $49 \%$ \\
\hline
\end{tabular}

The occupancy rate in the three inner city zones (zones 1-3) remains virtually unchanged; the small changes are not significant. The shares of streets with occupancy level above 85 percent and 50 percent also remain unchanged. Moreover, the share of cars with resident parking permit remains unchanged, despite the price increase. In the CBD, where the fee increased from $€ 4.2$ to $€ 5 / h$, the occupancy rate increased! The increase is partly a result of a reduced capacity for street parking in the $\mathrm{CBD}$ (mainly due to ongoing construction works). However, the actual number of parked cars also increased by about $11 \%$, so reduced capacity is not the only reason for the increased occupancy rate.

In 2013, however, the charge was increased from $€ 2.6$ to $€ 4.1$ /hour in the CBD. According to analyses by Cats et al. [2], the increase in the fee then resulted in a significant reduction in the occupancy rate. This suggests that the price elasticity is nonlinear, and more price-sensitive drivers are priced off the road. Another possible reason for the smaller impact of the more recent increase is that at the same time, parking fees were introduced in the suburbs. Hence it becomes less attractive to adapt to parking fee increases in the inner city by moving the car to the suburbs.

\subsection{Zone4}

Because of the introduction of street-parking fees in the inner suburbs during the spring of 2017, the city of Stockholm also monitored occupancy rates and the number of illegally parked cars by manual counts in 150 randomly selected blocks in zone 4. Data was collected in daytime (7am - 7pm) and evening time (after 7pm) in three waves: April / May 2016 (before the new parking fees), Sept / Oct 2017 (a few months after the introduction) and April - May 2018 (one year after the introduction of the parking fee).

Again, the number of parked cars is counted once for every selected block, such that each street generates one observation per data collection period. The number of cars is converted to occupancy rate by dividing by maximum capacity. Table 5 shows the average occupancy rate over all streets by data collection period, time-of-day and type of area (block of multifamily buildings, single-family houses, and areas with nonresidential buildings (e.g, sports grounds, shops etc.)). Initially the occupancy rate was higher in the evening than in the daytime in all types of areas, and highest in multi-family building areas.

Table 5. Occupancy Rate etc. in Zone f4 Weekdays, Before and After Parking Fees Apply. the Figures in Brackets Show that Occupancy Rate Account Parking Capacity had Remained Constant.

\begin{tabular}{|c|c|c|c|}
\hline Zone 4, weekday & $\begin{array}{l}\text { April/May } 2016 \\
\text { (before) }\end{array}$ & $\begin{array}{l}\text { Sept/Oct } 2017 \\
\text { (a few months after) }\end{array}$ & $\begin{array}{l}\text { April/May } 2018 \\
\text { (1 y after) }\end{array}$ \\
\hline Occupancy rate, multi-family building areas, day & $85 \%$ & $56 \%$ & $77 \%(62 \%)$ \\
\hline Occupancy rate, multi -family building areas, evening & $92 \%$ & $79 \%$ & $88 \%(72 \%)$ \\
\hline Occupancy rate, one-family house areas, day & $43 \%$ & $15 \%$ & $23 \%(22 \%)$ \\
\hline Occupancy rate, one-family house areas, evening & $44 \%$ & $24 \%$ & $22 \%(22 \%)$ \\
\hline Occupancy rate, non-residential buildings areas, day & $77 \%$ & $44 \%$ & $63 \%(50 \%)$ \\
\hline Occupancy rate, non-residential buildings areas, evening & $81 \%$ & $53 \%$ & $66 \%(50 \%)$ \\
\hline
\end{tabular}

The introduction of parking fees in the inner suburbs reduced the occupancy rates substantially. The occupancy rate declined shortly after the introduction but increased slightly again during the following year. However, this increase in the occupancy rate is partly due to a reduction in parking capacity. Between the autumn of 2017 and the spring of 2018, the 
number of parking places decreased by 19 percent in multifamily residential areas, by 7 percent in single-family areas and 21 percent in other areas. Had the number of parking places remained constant, the occupancy rate would have changed less between the second and third data collection wave, as shown by the figures in brackets.

Although the fees do not apply in the evening, the occupancy rate decreased almost to the same extent in the evening, suggesting that the fees not only impact commuting behaviour. It suggests that the fees have encouraged residents in the neighbourhood or residents of the inner-city who previously parked their car in the suburbs to park their car in other areas, or to rent a parking space. It is also possible that they impacted car ownership. The fees also seem to have had almost the same effect in the evening in the areas with single-family buildings and non-residential buildings. The figures in bracket show that in the evenings the occupancy rate even continued to decrease between the second and the third data collection wave, indicating that the residents have more adaptation mechanisms available in the long term than in the short term. This result is in correspondence with that of $[29,30]$ who note that price impacts tend to increase over time as consumers have more options. The reduction in the number of vehicles and the number of parking places differs by type of area. Note, however, that there are quite a few observations in each area, so differences must be interpreted with caution.

In the areas comprising multi-family buildings, the average occupancy rate fell from 85 percent to approximately 60 percent. The share of streets with an occupancy rate above the target 85 percent fell from close to two-thirds to just below one-third. The parking fees thus served their purpose. At the same time, the occupancy rate was already low in many streets before the fees were introduced: 40 percent of the streets had an occupancy rate below the target 85 percent. After introduction of the fees, one-third of the streets have an occupancy rate below $50 \%$.

In the areas with one-family houses, the occupancy rate was already low, and it dropped even further after the introduction. In the other areas, with non-residential buildings, the occupancy rate was in between the areas with one-family houses and multi-family buildings, and the reduction was also substantial.

\subsection{Effects of Increasing the Penalty Charge}

Parking tickets are issued to cars parked in breach of parking regulations, to provide incentives to comply with the regulations and to pay the parking fees. However, few studies have explored the effectiveness of parking tickets, and the amount of the fine. In Stockholm, the penalty charges were raised in 2012 and again in 2017, providing an opportunity to explore the impact on the number of cars violating the restriction in the amount of the penalty charge. The amount of the penalty charge has three levels, depending upon how serious the contravention is. The table below shows the amount of the penalty charges by severity of the contravention.

Table 1. The Amount of Penalty Charge, by Severity of the Contravention.

\begin{tabular}{llll}
\hline Year & Overstaying on a pay and display bay & Parking causing obstruction & Parking causing severe obstruction or risk of accidents \\
\hline 2012 & $€ 55$ & $€ 65$ & $€ 100$ \\
2017 & $€ 75$ & $€ 85$ & $€ 120$ \\
\hline
\end{tabular}

Figure 4 shows the share of vehicles complying with the parking regulations in the inner city (zones 1-3). The data is collected as part of the data collection described in Section 3.1 , undertaken twice a year in the 483 randomly selected blocks in the inner city. The share of vehicles violating the parking regulations by breaking some traffic rules (not parking in a permitted place) is currently only a few percent, but the share of vehicles violating the regulations by not paying the charge within the prescribed period is approximately 15 percent in the inner city, and even lower in zones 4 and 5 .

There is a steady trend increase in the share of vehicles complying with the parking regulations from 2007 to 2015 . The trend increase is not related to the increase in the amount of the penalty charge in 2012: the trend is steady over the 8 years, whereas the amounts only increased once. The following increase in the penalty charge in 2017 had no effect on the share of the vehicles violating the parking restrictions. According to experts in the city of Stockholm, the enforcement of cars violating the parking restrictions has not become more intense or more diligent over the years, so the driver of the trend increase is unknown. A potential reason could be the implementation of smart cashless mobile apps, allowing the driver to adjust an ongoing parking session and remind the driver before it expires.

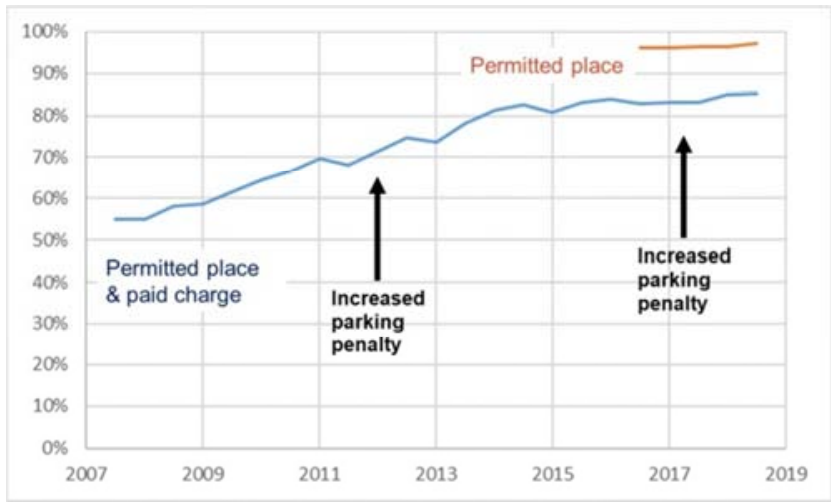

Figure 4. Share of vehicles complying with the parking regulations in the inner city (zones 1-3). Data was collected in daytime (7am - 7pm) on 483 randomly selected blocks twice a year, during weekdays daytime (7am$7 p m)$.

\section{Floating Car Data}

In order to explore the impact of introducing parking fees in zone 4 in greater depth, floating car data measurements 
were conducted in the area of Midsommarkransen (Figure 3). When using this data, we can cancel out any effect on changes in the parking capacity between the data collection periods. The data collection is based on video recording of the street-parking spaces on the selected road stretches, a floating car equipped with data logger and GPS system for automatic position determination. Video registration took place in the direction of the car, where the number of parked cars on both sides of the street was counted. When occupancy fluctuates strongly by time of day, as we predicted in our study, it is essential to follow exactly the same routes at exactly the same time every day [31] so the floating car drove exactly the same routes at exactly the same time of day for all measurement days.

The on-street parking fee was introduced in January 2017 in the area under study. Our data was collected in three waves: the first in the autumn of 2016, before the introduction of the on-street parking fee, the second in the spring of 2017 and the third in the autumn of 2017. The third wave took place exactly one year after the first wave such that we can control for seasonal effects. Each data collection period took place over two weeks, including three weekdays each: Monday, Wednesday and Friday and every measurement day included three observation periods: 8-10, 11-13 and 17-19. Within each observation period the floating car made approximately 100 observations. One observation corresponds to an uninterrupted road stretch. To balance out the variation across days, we compute the mean of all observations made over the two weeks, by time-of-day and weekday, resulting in one observation per uninterrupted road stretch, weekday and time-of-day period. The total number of observations obtained in autumn 2016, in spring 2017, and in autumn 2017, respectively, is shown in Table 7.

Table 2. Schedule for Data Collection for Before and After Introduction of on-Street Parking Fee.

\begin{tabular}{|c|c|c|c|c|c|c|c|c|c|c|c|c|c|c|c|c|c|c|}
\hline & \multicolumn{3}{|c|}{ Monday } & \multicolumn{3}{|c|}{ Wednesday } & \multicolumn{3}{|c|}{ Friday } & \multicolumn{3}{|c|}{ Monday } & \multicolumn{3}{|c|}{ Wednesday } & \multicolumn{3}{|c|}{ Friday } \\
\hline & \multicolumn{3}{|c|}{$2016 / 11 / 21$} & \multicolumn{3}{|c|}{$2016 / 11 / 23$} & \multicolumn{3}{|c|}{$2016 / 11 / 25$} & \multicolumn{3}{|c|}{$2016 / 11 / 28$} & \multicolumn{3}{|c|}{$2016 / 11 / 30$} & \multicolumn{3}{|c|}{$2016 / 12 / 02$} \\
\hline & $8-10$ & $11-13$ & $17-19$ & $8-10$ & $11-13$ & $17-19$ & $8-10$ & $11-13$ & $17-19$ & $8-10$ & $11-13$ & $17-19$ & $8-10$ & $11-13$ & $17-19$ & $8-10$ & $11-13$ & $17-19$ \\
\hline \multirow[t]{3}{*}{ Aut. 2016} & 92 & 88 & 108 & 92 & 92 & 108 & 94 & 93 & 108 & 88 & 88 & 108 & 92 & 92 & 108 & 93 & 93 & 108 \\
\hline & \multicolumn{3}{|c|}{$2017 / 06 / 19$} & \multicolumn{3}{|c|}{$2017 / 06 / 21$} & \multicolumn{3}{|c|}{$2017 / 06 / 16$} & \multicolumn{3}{|c|}{$2017 / 06 / 26$} & \multicolumn{3}{|c|}{$2017 / 06 / 28$} & \multicolumn{3}{|c|}{$2017 / 06 / 30$} \\
\hline & 8 & 11 & 17 & 8 & 11 & 17 & 8 & 11 & 17 & 8 & 11 & 17 & 8 & 11 & 17 & 8 & 11 & 17 \\
\hline \multirow[t]{3}{*}{ Spr. 2017} & 90 & 90 & 108 & 94 & 94 & 108 & 97 & 97 & 108 & 94 & 90 & 108 & 94 & 94 & 108 & 97 & 97 & 108 \\
\hline & \multicolumn{3}{|c|}{$2017 / 12 / 11$} & \multicolumn{3}{|c|}{$2017 / 12 / 06$} & \multicolumn{3}{|c|}{$2017 / 12 / 08$} & \multicolumn{3}{|c|}{$2017 / 12 / 18$} & \multicolumn{3}{|c|}{$2017 / 12 / 13$} & \multicolumn{3}{|c|}{$2017 / 12 / 15$} \\
\hline & 8 & 11 & 17 & 8 & 11 & 17 & 8 & 11 & 17 & 8 & 11 & 17 & 8 & 11 & 17 & 8 & 11 & 17 \\
\hline Aut. 2017 & 87 & 87 & 105 & 92 & 92 & 105 & 94 & 94 & 105 & 87 & 87 & 105 & 92 & 92 & 105 & 94 & 94 & 105 \\
\hline
\end{tabular}

\section{Results}

When analyzing the impact of introducing the parking fees, we used only the observations from road stretches from which we had observations from all three data collection periods. This cancels out any impact of reduced parking capacity between the data collection periods.

Table 8 presents the descriptive statistics. The average number of parked cars by time of day period is depicted in Figure 5. First, we note the general pattern in the autumn of 2016 , that the number of parked cars is lowest in the morning period 8-10 and highest in the evening 17-19, confirming the results of table 5. This pattern suggests that most of the parked cars belong to residents of the area, some driving to work in the morning, and coming back in the evening. On Mondays and Wednesdays, the number of parked cars is higher in the mid-day period than in the morning, suggesting more visits from non-residents in these weekdays.

The number of parked cars declined by $35-40 \%$ percent between the autumn of 2016 (without parking fees) and the spring of 2017 (with parking fees). Then the number of parked cars remained fairly unchanged the rest of the year, until the autumn of 2017, indicating that the seasonal effect is limited and that the full impact of the parking fees occurred within a few months after their introduction. Figure 4 shows that the average number of parked cars for the road stretches shows a significant (at most at the 5\%-significance level) decrease between spring 2016 and spring 2017.

The pattern of variation in the number of parked cars by weekday and time-of-day period is virtually identical in all three data collection waves. This also confirms the result of Table 7 . The difference in the number of cars by road segment is presented in Figure 7 . As can be seen, a majority of segments decreased by more than $50 \%$.

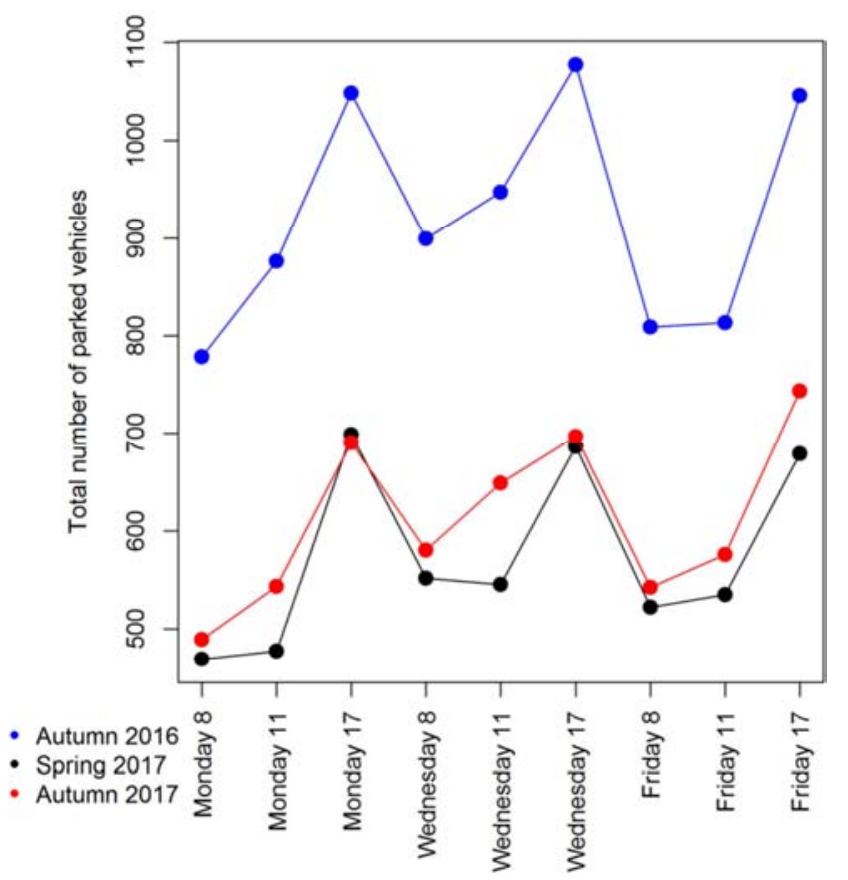

Figure 5. The average number of parked cars by time-of-day and weekday for autumn 2016, spring 2017 and autumn 2017. 

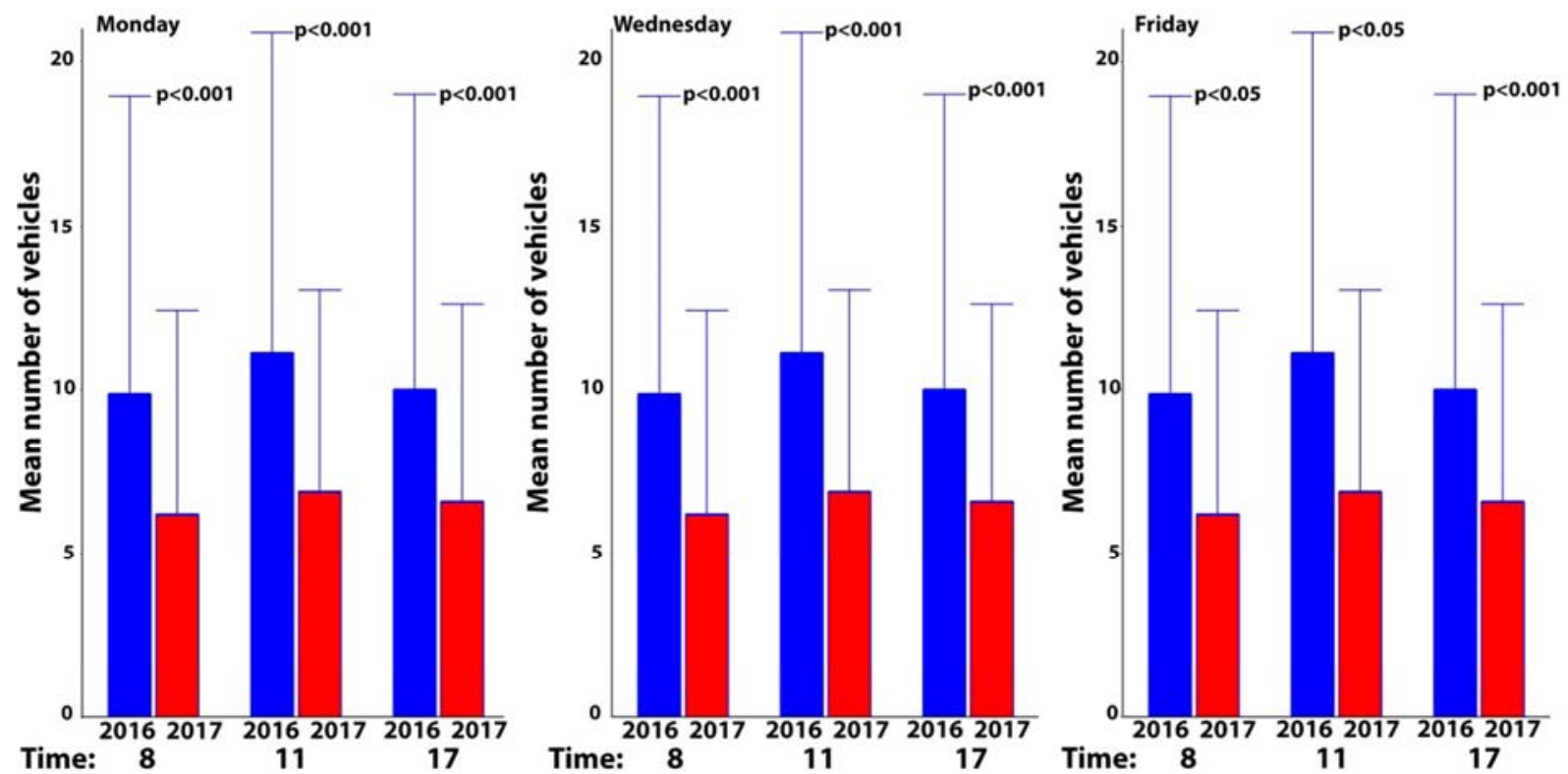

Figure 6. The mean number of parked cars by time-of-day and weekday, autumn 2016 and autumn 2017. The p-values correspond to the t-test of the 2016 and 2017 observations.

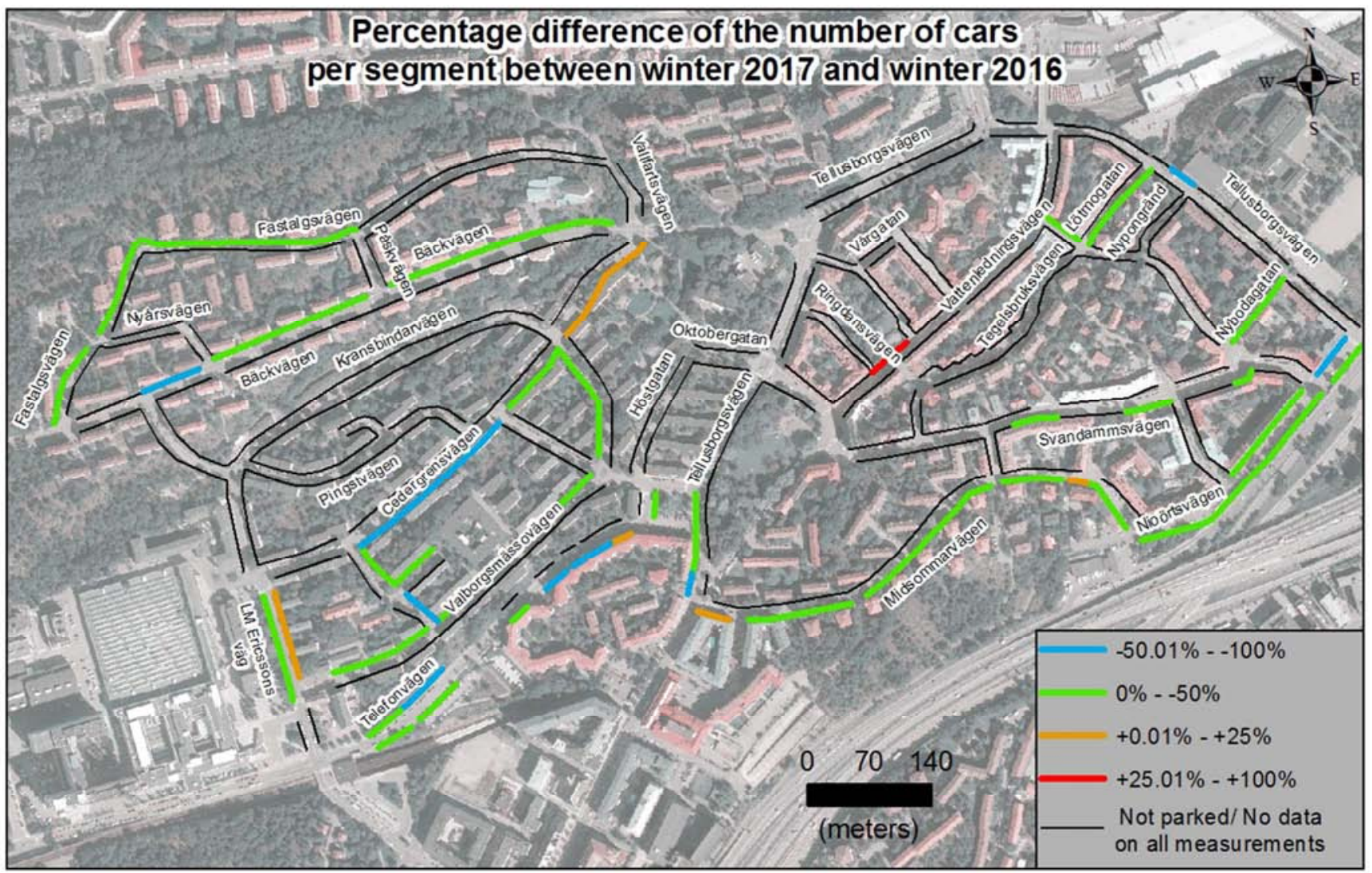

Figure 7. Difference in the number of parked cars by segment between autumn 2016 and autumn 2017.

Table 8. Number of observations (road stretches) and statistics by data collection period and time-of-day.

\begin{tabular}{|c|c|c|c|c|c|c|c|c|c|c|c|c|c|}
\hline & & \multicolumn{12}{|c|}{ Time of day } \\
\hline & & \multicolumn{4}{|c|}{$8-10$} & \multicolumn{4}{|c|}{ 11-13 } & \multicolumn{4}{|c|}{$17-19$} \\
\hline & & No & Sum & Mean & SD & No & Sum & Mean & SD & No & Sum & Mean & SD \\
\hline Autumn 2016 & & 79 & 779 & 9.85 & 9.11 & 79 & 877 & 11.09 & 9.79 & 105 & 1049 & 9.99 & 9.03 \\
\hline Spring 2017 & Monday & 79 & 469 & 5.94 & 5.35 & 79 & 478 & 6.04 & 5.05 & 105 & 699 & 6.65 & 5.62 \\
\hline Autumn 2017 & & 79 & 489 & 6.19 & 6.22 & 79 & 544 & 6.88 & 6.16 & 105 & 690 & 6.57 & 6.03 \\
\hline
\end{tabular}




\begin{tabular}{|c|c|c|c|c|c|c|c|c|c|c|c|c|c|}
\hline & & \multicolumn{12}{|c|}{ Time of day } \\
\hline & & \multicolumn{4}{|c|}{$8-10$} & \multicolumn{4}{|c|}{$11-13$} & \multicolumn{4}{|c|}{ 17-19 } \\
\hline & & No & Sum & Mean & SD & No & Sum & Mean & SD & No & Sum & Mean & SD \\
\hline Autumn 2016 & & 90 & 665 & 9.50 & 9.37 & 90 & 731 & 10.44 & 10.21 & 105 & 1049 & 9.99 & 9.03 \\
\hline Spring 2017 & Wednesday & 90 & 407 & 5.65 & 5.33 & 90 & 416 & 5.78 & 5.08 & 105 & 699 & 6.65 & 5.62 \\
\hline Autumn 2017 & & 90 & 408 & 5.66 & 6.46 & 90 & 447 & 6.20 & 6.53 & 105 & 690 & 6.57 & 6.03 \\
\hline Autumn 2016 & & 87 & 649 & 9.41 & 8.86 & 87 & 717 & 10.38 & 9.36 & 105 & 1049 & 9.99 & 9.03 \\
\hline Spring 2017 & Friday & 87 & 374 & 5.27 & 5.10 & 87 & 389 & 5.47 & 4.88 & 105 & 699 & 6.65 & 5.62 \\
\hline Autumn 2017 & & 87 & 369 & 5.20 & 5.86 & 87 & 431 & 6.07 & 6.02 & 105 & 690 & 6.57 & 6.03 \\
\hline
\end{tabular}

Now we turn to studying the occupation rate instead of the number of parked cars. Distinct parking spaces were not painted on the street in any of the road segments. For this reason, we assume that each parking space is 5.5 metres, and calculate the occupancy rate by dividing the length of the road stretch by 5.5 metres. The mean occupancy rate in the autumn 2016 was 53 percent and in the autumn 2017 it was 35 percent, yielding a decrease of 34 percent between the two years.

Our finding that the reduction in the number of parked cars is similar in all time-of-day periods and weekdays is consistent with the result from Section 3.2, also finding a substantial impact in the evening period. This suggests that the main driver behind the reduction is not changed commuting behaviour. Rather, car owners residing in the study area and residents of the inner city who (previously) had parked their cars in the study area have either rented a parking space or moved the car to neighbourhoods further out in the suburbs where street parking is still free. A reduction in car ownership is also possible.

\section{Concluding Remarks and Policy Implications}

This paper analyses the effect of introducing on-street parking fees of $€ 1$ /hour on workdays $7 \mathrm{am}-7 \mathrm{pm}$ in the inner suburbs of Stockholm. We analyze before and after the data is conducted by floating car measurements. For comparison we analyze the impacts on parking occupancy of increased parking fees in the inner city and the introduced fees in the inner suburbs using more aggregate data collected by the city of Stockholm.

We observe a 35-40 percent reduction in the number of parked cars in response to the introduction of parking fees in the suburbs. A large increase in the suburbs is also confirmed by the aggregate data. However, the increase in the parking fee in the inner city of Stockholm had a substantially lower effect or no effect at all on the occupancy rate. So why is the impact of introducing charges higher in the suburbs than of increasing an already existing fee in the inner city? There could be several reasons. First, the larger impact in the suburbs is likely to be the low initial occupation rate. That is, there was no or marginal excess demand for parking space before the charges were introduced. In the central parts of Stockholm, however, there was a considerable excess demand for parking before the charges were increased, resulting in a smaller reduction.

Second, the effect of an increase in an existing parking fee could in general be greater than an introduction of a new fee.
Similar results were found for the congestion charge in Stockholm, Gothenburg and Singapore: the price elasticity of the charge was substantially larger at the introduction than when the charges were increased $[28,32]$. The most likely reason for such an effect would be that the most pricesensitive drivers (and most flexible in terms of mode, destination and time of day) are already priced off the road at the first introduction. Hence, after the introduction of the parking fee, the flexibility and price sensitivity of the remaining drivers are on average lower. This means that the introduction of the parking fee has shifted the baseline situation from a flatter section of the demand curve to a section where the demand curve is steeper. Another explanation could be transaction costs when a new parking fee is introduced. The transaction cost itself could be one reason for the reduction. Yet another possible reason for the larger effect at the introduction than at an increase is a zeroprice effect, referring to the phenomenon that decisions concerning free goods differ from the decisions concerning priced goods. Shampanier et al. [33] find that the demand effect in response to a price increase is stronger if the good was initially free than if it was already priced. Some of the hypotheses they put forward, relating to mapping and anchoring, could apply to parking fees.

A third possible reason for the smaller impact of the more recent increase in the city is that parking fees were introduced in the suburbs at the same time. Hence it becomes less attractive for residents if the inner city to adapt to price increases in the inner city by moving their car to the suburbs.

In the suburbs, we also observe a substantial effect in the evening period, although the parking fees are only levied during daytime. In the more controlled floating car data, the effect is virtually the same in the evenings as during the day. This suggests that the main driver behind the reduction is not changes in the commuting behaviour, among residents, parkand-ride commuters or those commuting to the area.

Instead, the adaptations seem to be among the residents of the area, or among residents of the inner city who (previously) parked their cars in the suburb to avoid the parking fees in the inner city. They could adapt by reducing car ownership, more residents paying for a private parking space, or residents parking their car outside the residential area (study area); further from the central city, on-street parking is still free. It is probable that all these adaptation mechanisms are at play at the same time.

So, it is effective to introduce parking fees in the suburbs, but is this a good policy? Well, it might be. Underpriced streetparking for residents in the suburbs distorts the land market: the supply of parking on private land becomes too low in relation to demand. It also limits the supply of parking space for visitors. 
But the same argument can be used against discounts of parking for residents (residents' parking permits) so parking fees in the suburbs in combination with residents' parking permits is not really consistent. A negative effect of fees for street parking in the suburbs is that it might result in more cars in the inner city, since residents of the inner city park their cars in the suburbs to avoid parking fees. Hence, it could be a good idea to introduce on-street parking fees in the suburbs. However, in that case we would advise against leaving evenings uncharged, since the occupancy rate is actually higher then. It also makes little sense to have resident parking permits in combination with parking fees in the suburbs.

\section{Orchid}

Albania Nissan; https://orcid.org/0000-0001-9338-5509

Ioannis Ntriankos; http://orcid.org/0000-0002-8802-6955

Jonas Eliasson; http://orcid.org/0000-0003-1789-9238

Per Näsman; http://orcid.org/0000-0001-7606-8771

Maria Börjesson; http://orcid.org/ 0000-0001-9235-0232

\section{References}

[1] D. C. Shoup, "Cruising for parking”, Transp. Policy, vol. 13, nr 6, s. 479-486, nov. 2006, doi: 10.1016/j.tranpol.2006.05.005.

[2] O. Cats, C. Zhang, och A. Nissan, "Survey methodology for measuring parking occupancy: Impacts of an on-street parking pricing scheme in an urban center", Transp. Policy, vol. 47, s. 55-63, apr. 2016, doi: 10.1016/j.tranpol.2015.12.008.

[3] E. Madsen, I. Mulalic, och N. Pilegaard, "A model for estimation of the demand for on-street parking", MPRA Paper 52301, dec. 2013. Åtkomstdatum: sep. 30, 2019. [Online]. Tillgänglig vid: https://mpra.ub.uni-muenchen.de/52361/.

[4] G. Marsden, "The evidence base for parking policies-a review", Transp. Policy, vol. 13, nr 6, s. 447-457, nov. 2006, doi: 10.1016/j.tranpol.2006.05.009.

[5] D. B. Ottosson, C. Chen, T. Wang, och H. Lin, "The sensitivity of on-street parking demand in response to price changes: A case study in Seattle, WA", Transp. Policy, vol. 25 , s. 222-232, jan. 2013, doi: 10.1016/j.tranpol.2012.11.013.

[6] S. Concas och N. Nayak, "A Meta-analysis of Parking Pricing Elasticity", presenterad vid Transportation Research Board 91st Annual MeetingTransportation Research Board, 2012, Åtkomstdatum: sep. 30, 2019. [Online]. Tillgänglig vid: https://rid.trb.org/view/1130741.

[7] M. B. W. Kobus, E. Gutiérrez-i-Puigarnau, P. Rietveld, och J. N. Van Ommeren, "The on-street parking premium and car drivers' choice between street and garage parking", Reg. Sci. Urban Econ., vol. 43, nr 2, s. 395-403, mar. 2013, doi: 10.1016/j.regsciurbeco.2012.10.001.

[8] J. Simićević, S. Vukanović, och N. Milosavljević, "The effect of parking charges and time limit to car usage and parking behaviour", Transp. Policy, vol. 30, s. 125-131, nov. 2013, doi: 10.1016/j.tranpol.2013.09.007.

[9] J. A. Kelly och J. P. Clinch, "Temporal variance of revealed preference on-street parking price elasticity”, Transp. Policy, vol. 16, $\mathrm{nr} 4, \quad$ s. 193-199, aug. 2009, doi: 10.1016/j.tranpol.2009.06.001.

[10] A. Gragera och D. Albalate, "The impact of curbside parking regulation on garage demand", Transp. Policy, vol. 47, s. 160168, apr. 2016, doi: 10.1016/j.tranpol.2016.02.002.

[11] K. Huang, Z. Liu, T. Zhu, I. Kim, och K. An, "Analysis of the acceptance of park-and-ride by users: A cumulative logistic regression approach", J. Transp. Land Use, vol. 12, nr 1, juli 2019, doi: 10.5198/jtlu.2019.1390.

[12] L. Márquez, L. F. Macea, och J. J. Soto, "Willingness to change car use to commute to the UPTC main campus, Colombia: A hybrid discrete choice modeling approach", $J$. Transp. Land Use, vol. 12, $\mathrm{nr}$ 1, maj 2019, doi: 10.5198/jtlu.2019.1460.

[13] R. J. Schneider, "Local environment characteristics associated with walking and taking transit to shopping districts", 2015, doi: $10.5198 /$ jtlu.2015.666.

[14] D. S. Vale, M. Pereira, och C. M. Viana, "Different destination, different commuting pattern? Analyzing the influence of the campus location on commuting", J. Transp. Land Use, vol. 11, nr 1, s. 1-18, 2018.

[15] P. van den Berg, K. Geurs, S. Vinken, och T. Arentze, "Stated choice model of transport modes including solar bike", $J$. Transp. Land Use, vol. 11, nr 1, s. 901-919, 2018.

[16] S. A. H. Zahabi, L. F. Miranda-Moreno, Z. Patterson, och P. Barla, "Evaluating the effects of land use and strategies for parking and transit supply on mode choice of downtown commuters", J. Transp. Land Use, vol. 5, nr 2, okt. 2012, doi: 10.5198/jtlu.v5i2.260.

[17] G. Albert och D. Mahalel, "Congestion tolls and parking fees: A comparison of the potential effect on travel behavior", Transp. Policy, vol. 13, nr 6, s. 496-502, nov. 2006, doi: 10.1016/j.tranpol.2006.05.007.

[18] D. A. Tsamboulas, "Parking fare thresholds: a policy tool", Transp. Policy, vol. 8, nr 2, s. 115-124, apr. 2001, doi: 10.1016/S0967-070X(00)00040-8.

[19] W.-S. Ng, "Work schedule flexibility and parking preferences”, 2017, doi: 10.5198/jtlu.2016.554.

[20] L. Lehe, "Feedback and the use of land for parking", J. Transp. Land Use, vol. 10, nr 1, s. 463-476, 2017.

[21] R. Arnott, E. Inci, och J. Rowse, "Downtown curbside parking capacity", J. Urban Econ., vol. 86, s. 83-97, mar. 2015, doi: 10.1016/j.jue.2014.12.005.

[22] S. Brooke, S. Ison, och M. Quddus, "On-street parking search: A UK local authority perspective", J. Transp. Land Use, vol. 10, nr 1, s. 13-26, 2017, doi: 10.5198/jtlu.2015.600.

[23] S. P. Anderson och A. de Palma, "The economics of pricing parking", J. Urban Econ., vol. 55, nr 1, s. 1-20, jan. 2004, doi: 10.1016/j.jue.2003.06.004.

[24] J. (Brian) Lee, D. Agdas, och D. Baker, "Cruising for parking: New empirical evidence and influential factors on cruising time", J. Transp. Land Use, vol. 10, nr 1, okt. 2017, doi: 10.5198/jtlu.2017.1142.

[25] R. Cervero, "Sustainable new towns: Stockholm's rail-served satellites", Cities, vol. 12, nr 1, s. 41-51, feb. 1995, doi: 10.1016/0264-2751(95)91864-C. 
[26] Stockholm City Planning Administration, "Stockholm City Plan Summary, May 2009”. 2009, [Online]. Tillgänglig vid: www.stockholm.se.

[27] J. Eliasson, "Lessons from the Stockholm congestion charging trial", Transp. Policy, vol. 15, nr 6, s. 395-404, nov. 2008, doi: 10.1016/j.tranpol.2008.12.004.

[28] M. Börjesson och I. Kristoffersson, "The Swedish congestion charges: Ten years on", Transp. Res. Part Policy Pract., vol. 107, nr Supplement C, s. 35-51, jan. 2018, doi: 10.1016/j.tra.2017.11.001

[29] M. Börjesson, J. Eliasson, M. B. Hugosson, och K. BrundellFreij, "The Stockholm congestion charges-5 years on. Effects, acceptability and lessons learnt", Transp. Policy, vol. 20, s. 1-12, mar. 2012, doi: 10.1016/j.tranpol.2011.11.001.

[30] P. Goodwin, J. Dargay, och M. Hanly, "Elasticities of road traffic and fuel consumption with respect to price and income: a review", Transp. Rev., vol. 24, nr 3, s. 275-292, 2004.
[31] A. Millard-Ball, R. R. Weinberger, och R. C. Hampshire, "Is the curb $80 \%$ full or $20 \%$ empty? Assessing the impacts of San Francisco's parking pricing experiment", Transp. Res. Part Policy Pract., vol. 63, s. 76-92, maj 2014, doi: 10.1016/j.tra.2014.02.016.

[32] P. Olszewski och L. Xie, "Traffic Demand Elasticity with Respect to Road Pricing -- Some Evidence from Singapore", Proc. Int. Conf. Seamless Sustain. Transp, 2002. Åtkomstdatum: juli 02, 2016. [Online]. Tillgänglig vid: https://www.researchgate.net/profile/Piotr_Olszewski2/public ation/261712681_Traffic_demand_elasticity_with_respect to road_pricing_some_evidence_from_Singapore/links $/ 0 \mathrm{a} 85 \mathrm{e}$ $\overline{5} 3540 \mathrm{cb} 5 \mathrm{a} 2 \mathrm{fcd} 00000 \overline{0}$.pdf.

[33] K. Shampanier, N. Mazar, och D. Ariely, "Zero as a special price: The true value of free products", Mark. Sci., vol. 26, nr 6, s. 742-757, 2007. 